ギーで一致しない点, 半価尿值が $40 \mathrm{kV}$ で愦差が大きい 点等は前 2 題の演題と同様に，測定器のエネルギー特性 によるものではないだるうか：との研究発表は散乱X線 6合めた広範毌の測定が簡単に可能なしとから，今後の 研究を期待したい.

最後に，X線束の実効エネルギ一は半価副值加ら一般 に求められているが，ファントム中のX線束の実效エネ ルギーを測定する時 narrow beam の測定からで良いの 加（広島大：砂屋敷）の复問に対し，本来半価層值加 笑效エネルギーを求めるのは一次線束の測定になってい る.ファントム中での測定は散乱有度分布が問題となる （京大：佐藤）との事で，一次線束ならびに吸収体透過 後の笠エネルギ一測定法について，今後，さらに半価 層佃，スペクトル測定法の研究を期待したいと思いま す.

\section{管理-6 防護用具他}

座長 深 栖一（早期胃がえ検彰センター）

\section{5. 通気性 X線防護前掛の試作}

千葉䍗がんセンター放射線搒断部

○勢登和夫：毛和快晴・佐藤，等 永拉義衛・佐藤安雄・笹本和夫 篠塚 稔? 高橋靖雄・真部示雄

從来の防護前掛は，JISの遮蔽性においては立分な物 であったが通気性においては不充分であった，命回試作 した防護前掛は遮蔽性をそとなう事なく通気性を備えた 防護前掛を試作した。含鉛ゴム 3 枚を使用し，各含鉛ゴ ムに通気性が出来る様に通気孔を連続して設ける。通気 孔の位置は 3 枚の含鉛ゴムのうち 1 枚の通気孔の位置力 他の 2 枚と重ならない様に，ずらして開ける。3枚の含 鉛ゴムの間には通気性を持った厚さのある綿メッシュを 入れサンドイッチ状に重ねた，測定の結果，重量・散乱 線の遮蔽能力屯，従来の防謢前掛之同等で，着用時も通 気性が一段之良くなり満是すべき結果が得られた。

\section{6. 含鉛アクリル樹脂製尿道撮影用防護衝立の試作}

国立熱海病院 ○乾 三郎・整野貞 $\rightarrow$ 拹和ガス化学工業株式会社 鈴木敏之・阿部 均

我が国の人口の高榆化にともない男子逆行性尿道撮影 (以下尿道撮影という) は増加の一途をたどっている。 この尿道撮影についてアンケート調査を行なったととる (回答のあった67施設） $92.5 \%$ が造影剤を外尿道日へ手 圧で注入し，術者の合図でX線を懪射する方法（以下手 動という)で行なわれている，との術式は術者が常に被
曝の危険にさらされているもので被曝防護が敀務と思考 し，放射線しゃへい材として最近開発された含鉛アクリ ル樹脂板 (キョウワグラス-XA) を用い尿道撮影用衝立 を試作し，術者被曝防謢に良好な成果を得るととができ たのでしとに報告する。

\section{7. 後方散乱を用いたコンクリートの表面材に関する 研究}

東京大学生産技術研案所 $\bigcirc$ 斉櫒秀雄

放射線利用施設に扣いて放射線源加ら二次的に生成す る散乱 $\mathrm{X}, r$ 線をできる限り少なくすることが望まれて いる。特に理工学や核圄学などで使用されている密封さ れた放射性同位元素およひ線管球を利用する装置吕ら の一次放射線に上り壁や床加ら二次的に発生する放射線 度特性X線などを減らすととは放射線防護上特に重要で ある。このような観点加ら無限厚コンクリートから後方 散乱するX，r線成分を低減させる目的で鉄板およで鉛 箔を表面材として㙋布し，コンタリートのみからの散乱 成分之比較検討した：その結果一次 X，rのエネルギー 相違によりコンクリートの表面材料である鉄および鈆の 使し分けをしなければならないとと肪か力加。

\section{8. 暗室内における二酸化イオウ}

神奈川県予防医学協会

○萩原 明・武井恒夫・高橋公二 本条八洋・田中耕策・名波明尋 桶口政炤·広野実・宦下悦代 米川にずえ・松浦友子・中野孝夫

各病院大，診療所の暗室環境は，彷事する放射線技師， 助手にとっては良い環境とは思われないやに聞く。

今回，新設なった各暗室内の換気が著しく悪化し，暗 室内に発散する薬品により，腐食された金属類が露見し た。そこで金属僠食の原因を把捯し，今後の防錆対策に 資する目的に，使用している楽品のなか力ら発散の子測 される二酸化イオンを取り上げて測定を行なったので報 告をした。測定項目は，二酸イオウ，補集方法は，液体 捕集方法，分析方法は，吸光光度分析 $(\mathrm{p}-$ ロザリン法) 最屯高い濃度は，0.34 0.41 ppm，最毛低い濃度は， 0.01以下であった。

\section{座長集約}

管理一，乙のセッションは 4 原の発表かあり，放射 線防護 3 題, 暗室の環境改善て関するすの1題である.

395㢂は防謢用前掛に通気性をもたせるととによって 業務の能率化と診断效率をあげようとする意図がある。 このようなエ夫試作に対しては敬意を表したい。昨年 5 月，前捒 (Z4803)の JÍS 改正があり，鉛当量には， 0.25 